\title{
Edebiyat ve sosyoloji ilişkisi bağlamında alegorik ve gerçekçi rejim eleştirisi
}

\section{Yeliz OKAY}

\begin{abstract}
APA: Okay, Y. (2019). Edebiyat ve sosyoloji ilişkisi bağlamında alegorik ve gerçekçi rejim eleştirisi.
\end{abstract} RumeliDE Dil ve Edebiyat Araştırmaları Dergisi, (16), 280-159. DOI: 10.29000/rumelide.618816

\section{$\ddot{O} z$}

Toplumsal yapıda meydana gelen değişimleri ve sonuçlarını gözlemleyerek ortaya çıkan sosyal problemler üzerinde yorum yapan entelektüel, edebiyatçı, aydın ya da sanatçı, toplumda, toplumsal yaşamın dönüşümü ve etkileri konusunda bir farkındalık yaratma niyetiyle toplumsal fayda adına gözlemlerini kamuoyu ile paylaşır. Entelektüel, edebiyatçı, edebi eserin işlevsel niteliğini sanatsal niteliğinden daha ön plana çıkararak zaman zaman edebi eseri propaganda metnine zaman zaman da sistemi eleştiren edebî bir metine dönüştürebilir. Özellikle toplumların rejim değişikliği ile karşı karşıya kaldığı dönemde siyasetin sosyal yapı üzerindeki etkilerini konu edinen edebi eserlerin ve bu edebi eserleri veren sanatçıların dâhil olduğu edebî akımların ve sanat akımlarının ortaya çıkışı ve niteliği pek çok araştırmanın konusu olmuştur. Bu çalışmada farklı siyasi düşünceyi benimsemiş dönemin entelektüeli olarak kabul edilebilecek edebiyatçıların tek parti döneminin rejim eleştirisini yapan alegorik ve gerçekçi nitelikteki eserleri edebî eserin mevcut siyasi rejimi eleştirme niteliği ele alınarak incelenecektir.

Anahtar kelimeler: Toplumsal yapı, edebiyat sosyolojisi, sanat sosyolojisi, edebî eser, siyasi eleştiri.

\section{Allegory and realistic regime criticism in the context of the relationship between literature and sociology}

\begin{abstract}
Intellectual, literary or artist who comments on the social problems arising from observation of the changes and consequences of the social structure, shares his/her observations with the public on behalf of the social benefit with the intention of creating an awareness about the transformation and effects of social life in society. Intellectual, literary, can convert the literary work, from time to time to a propaganda text or a literary text criticizing the system by placing the functional property of literary work to the forefront compared to its artistic property. The emergence and quality of literary movements and artistic movements, which include literary works and the artists who prepare these literary works, have been the subject of many researches, especially when societies are faced with regime change. In this study; the allegorical and realistic works of the literary figures who have adopted a different political thought and criticize the regime of the one-party period of the period can be considered as intellectuals. The literary work will be examined by handling its criticizing property of the current political regime.
\end{abstract}

Keywords: Social structure, sociology of literature, sociology of art, literary works, political criticism. 


\section{Edebî eser aracılığı ile sanatçının siyasal eleştiri tutumuna kuramsal bakış}

Sanatçı, entelektüel, aydın, yazar, şair, eleştirmen toplumun içinden geçtiği ve sosyal dinamiklerini değiştiren süreçleri deneyimleyen kimliklerdir. Bir toplumsal ya da tarihsel olayın sosyal dinamikleri dönüştüren etkisi üzerinde izlenimlerini ifade etmenin ötesinde zaman zaman ideolojinin sözcüsü olarak da görülebilen kimlikler zaman zaman da kurgusal edebî ürünler yoluyla yaptıkları siyasal eleştirilerle toplumu farklı bir bakış açısının mümkün olduğu gerçeği ile yüzleştirirler. Bu anlamda edebiyat ve sosyoloji ilişkisinde siyasal eleştirinin hâkim olduğu eserler sanat sosyolojisinin imkanları ile değerlendirildiğinde bir anlamda edebî ürün Ali Akay’a göre (Akay,1999, s:10) sanat, siyaset veya sanat ve sosyoloji aralarındaki geçişlerle işlendiğinde işlevselleşmektedir. Akay, Jean Genet’in Sabra ve Şatila katliamlarında Filistin'in davasını kendi dilinin imkânları ile kendi ülkesinin politik tavrını da yararak küçük bir metinle ile ele alan sanatçı tutumundan yola çıkarak, yazarın selim bir edebî metni sosyal ve politik konum adına kullanmasının politik, poetik bağlamda sanatın gösterme yetisi olduğunu ifade eder (Akay, 1999, s:11).

Berna Moran, sanatçının edebî metni okura tarihsel ve toplumsal bulguları aktarmak adına işlevsel biçime dönüştürmesini sanatçının sanattan uzaklaşma tavrı olarak yorumlar (Moran, 1990, s:139). Araçsal nitelik kazanan edebî metin artık mevcut toplumsal yapının sosyolojik gerçekliğini netleştirir. Moran'a göre yazar, sezgilerini kullanan bir sosyologa dönüşür. Tarihsel ve toplumsal olguların yorumlanması için yazar roman türünü sosyolog gibi kullanırsa, roman kişisi olarak birey de araçsallaşır. Metindeki bireylerin dramı toplumun dramının temsiline dönüşür (Moran, 1990, s:139). 'Söz toplumbiliminden yoksunuz' diyen Roland Barthes de (Barthes, 2009, 61) devrimlerden beri yazarların dilini siyasal amaçlarla kendine mal eden kitlenin ortaya çıkışı ile Fransız toplumunda yazarların konuşan tek kişi olmadıklarını belirtir. Barthes, kurumsal anlamda Fransız dilinin sözcük dağarcığı ve akışı itibarıyla toplumda meydana gelen tüm siyasal ve sosyal sarsıntıya rağmen korunduğunu ifade eder.

Dilin işlevinin değişerek Chateaubriand veya Maistre'den, Hugo'ya veya Zola'ya yazarların kendilerinin de yazının işlevinin genişletilmesine, benimsedikleri ve sahipleri oldukları kurumlaşmış sözün yeni bir eylemin aracı yapılmasına katkıda bulunduklarını vurgulayan Barthes, yazarların kitle dilini elinde tutan yeni bir topluluk oluşturduğunun altını çizer (Barthes, 2009, s:61). Yazmanın bir bakıma dünyayı parçalamak ve yeniden yapmak olduğunu söyleyen Barthes, edebî eleştiri için 'bizi yazının gerçeğine götüren tarihin bir anından başka bir şey değildir' (Barthes, 2009, s:91)diyerek eleştirmenin metni ele alışının yönünü belirler. Ancak yazının eleştirilmesinden çok bu çalışmada ortaya konmak istenen mesele yazarın toplumsal yapıya etki eden siyasal otoriteyi eleştirme tutumundaki kimlikler arası rol geçişliliği yani toplumdaki değişimden etkilenen bireyken entelektüele dönüşümünün söz söylemeyi olanaklı kılan doğası ve işlevidir. Bu anlamda Edward Said, entelektüelin yabancılığının bir şeyleri değiştirme imkânlarına set çeken olağanüstü güçlü toplumsal otoritelerin -medyanın, hükümetlerin, büyük şirketlerin oluşturduğu ağ karşısında- kişinin kendini güçsüz hissetme gerçeği olduğunu vurgular. Said'e göre toplumu kontrol eden otoritenin toplumdaki değişimi istediği yönde gerçekleştirecek dinamikleri kontrollü hareket ettirmesi ya da toplumsal yapıyı değiştirmemek yönünde kontrol etmesi durumunda kitlenin farkında olmadığı gerçeğe entelektüelin tanıklığı yabancılaşmadır (Said, 2011, s:23) Said'in durumsal açıdan sürgün, marjinal ve yabancı olarak tanımladığı entelektüel, toplumu gözden geçirerek yeniden toplumsal olanı tanımlama gayreti içindeki ötekidir. Bu ötekilik sayesinde toplumun içinde olup toplum yararı esası ile siyasetin toplum üzerindeki etkilerine bakabilen entelektüel, edebiyatın imkânları ile sistemin işleyişi ve gündelik yaşama etki biçimlerini eleştirebilir. 
Toplumsal ve yazınsal koşulları bir ölçüye kadar siyasetin belirlediği düşünüldüğünde sosyal yapının değişim olgusuna bağlı olarak ortaya çıkan görünümlerinin edebî metindeki yansıması eleştiri niteliğindedir. Siyasetin güdümündeki edebiyat söz konusu olduğunda yeni bir rejimin toplum tarafından kabulü ve toplumun yeni rejim esaslarına göre dönüşümü için kaleme alınan edebî ürünlerde ideolojinin sözcülüğünün yazar tarafından yapılması, sistemin haklılaştırılması ve propaganda niteliği kazanır. Francis Merril, sosyologların, bir yazarın belli bir zamandaki belli bir toplumun belli bir sınıfın üyesi olduğu kanaatlerinden hareketle edebî metinde kendi çevresinin normlarını, beklentilerini, değerlerini anlattığını ifade eder (Merril, 2009, s:96). Said’in 'öteki' sınırlarında entelektüelin konumlandırmasından sonra Merril'in toplumsalı ifade eden yazarı toplumun içinden bir ses olarak konumlandırması siyaset, edebiyat ve sosyoloji ekseninde toplumun izahı meselesine bir başka ölçü olarak yorumlanabilir. Merril, edebiyata ilgi duyan sosyologlar ya da eleştirmenlerin okuyucunun okuduğu romandan çeşitli derecelerde etkilendiğini ve bu şekilde edebiyatın sosyal etkileşimi biçimlendirdiğini ifade etmektedir ve sosyolojik bakış açısına sahip eleştirmenlerin 'doğru'yu ima ile onaylama, 'yanlış'ı açıkça kınama biçiminde davranışları resmederek toplumsal normları pekiştirdiklerini vurgular (Merril, 2019, s:96).

Leo Lowenthal ise, yazarın inandırıcı karakterler geliştirerek onları içinde yaşadıkları toplum ve diğer kişilerle etkileşimde bulundukları ortamlara yerleştirerek sosyologlar için imkânsız olan deneyleri gerçekleştirebildiklerini ifade eder (Lowenthal, 2017, s:9). Bir anlamda toplumda kültürel ve sosyal dönüşümün mevcut siyasî iradeyi eleştirmek yoluyla gerçekleşebileceğine inanan düşünürlerden Horkheimer, Adorno ve Marcuse bu konuda aynı çizgide görüşler belirterek edebî metindeki düzen eleştirisinin kamuoyu oluşturma yeterliliğini ifade etmişlerdi (Moodie, 2010, s:2). Wittgenstein dili, edebî üretim ve şiirsel biçimler aracılığı ile kendisine sosyal dünyayı açıklama ve büsbütün dönüştürme yetkinliği kazandıracak usuller içerisinde belirgin toplumsal ilişkileri durmaksızın tespit ve inşa edilmesi olarak tanımlar (Harrington, 2019, s:109. Dilin imkânlarını kullanarak toplumun ve siyasal sistemin olumsuz yönlerini ortaya koyma gayreti içinde olan yazar, edebiyatın imkânlarını toplumsal fayda yönüyle kullanabilir demek mümkündür.

Edebiyat ile sosyolojinin arasında çeşitli kültür ürünlerinin arasındakinden daha fazla ortaklık olduğunu belirten Bauman, roman yazarları ile sosyolojik metin yazarlarının ayn toplumu incelediklerine vurgu yapar. Bauman, yazarların çoğu sosyologun fark edemeyeceği veya umursamayı marjinal olmaları veya sözde geri dönüşsüz biçimde azınlık statüsüne düşürülmeleri nedeniyle ilgilenmedikleri bir aşamada, yeni kopuşları tespit edip yakalayabildiklerini belirtir (Bauman, 2019, s:11). Modern zamanlarda roman yazarları kamusal tefekkürlerin ve tartışmaların ve farıılığın avangardı içinde film yapımcıları ve görsel sanatçllarla yan yana gelerek tüketim toplumunun denetimsiz, atomize olmuş özelleştirilmiş sosyal yapısı içinde bireyin yeni koşullarını anlatarak sosyoloji gibi disiplinlerce anlaşılmasına öncülük ederler (Bauman, 2019, 14). Bu anlamda bireyi yaşadı $\breve{g} ı$ toplumun toplumsal yapısını doğrudan etkileyen siyasal sistemin ve diğer toplumsal değişkenlerin öznesi olarak ele alan edebî metinler bireyin, siyasal sistem ve diğer değişkenlerin etkisi ile şekillenen gündelik hayatını ve sorunlarını zaman zaman hikâyeleştirir; zaman zaman da şiire, tiyatro eserine ve romana dönüştürür. Birey-toplum etkileşimi içinde bireyi ya da toplumu merkeze alan yazar, olgusal olarak da yaptığı değerlendirmeler ile siyasal sistem ve toplumsalın eleştirisini yapar. Sosyolojinin bir alt alanı olan edebiyat sosyolojisi, tarih, siyaset, toplum çerçevesinde edebî metinleri kendi döneminin toplumsal yapısının gündelik hayat görünümlerini yansitması itibarıyla ele alır.

Edebiyat sosyolojisi, edebî eserlerle onların doğdukları toplumlar arasındaki bağları ve yansımaları araştırır. Edebiyat yapıtı, ister gerçekçi isterse kurmaca olsun yazarın toplumsal ve kültürel 
birikimlerinin, içselleştirdiği şeylerin esere yansımasından dolayı, o eserde, topluma ve o toplumun insanına, kültürüne ve değerlerine, duygularına ilişkin bir şeyler bulur ve sosyolojik malzemeye dönüştürür. Her açıdan sosyal yaşamı yansıtan edebiyat metinleri hayatı keşfetmede, irdelemede, analiz etmede temel araçlardan biri kabul edilir (Alver, 2006, 113). Bu anlamda edebî metin, edebiyatçı aracılığı ile kendi çağının ve toplumunun aynası aynasına dönüşür. Kendi çağının bu güne kalmış aynası olarak George Orwell’in politik bağlamda toplumsal yarar edimini yazma dürtüsünün kaynağı olarak göstermesi önemlidir. Yazarın meselesi yaşadığı çağ tarafından belirlenecektir diyen Orwell, yazarların yazma dürtülerini sıralarken şeyleri oldukları gibi görme, gerçekleri bulma, gelecek nesillerin kullanımı için saklama arzusunun yanında politik sözcügünü en geniş anlamıyla kullandığını belirtir. Dünyayı belirli bir yöne götürme, diğer insanların uğrunda çabalamaları gereken toplumun nasıl bir şey olduğu hakkındaki fikirleri değiştirme dürtüsü olduğundan bahseder (Orwell, 2017, ss:10-11). Orwell'in politik dürtüden bağımsız barışçl, şatafatlı, betimleyici kitaplar yazabilecekken kendi deyişi ile 'propagandacı' olarak yazmasının nedeni otoriteyle karşı karşıya gelmesidir (Orwell, 2017, s:11). Diğer bir ifadeyle otoritenin gücünü toplumun içinde yaşayan birey olarak hissediş biçimi kendisini propagandist tavırla yazmaya sevk etmiştir. Orwell, kendisine uygun olmadığı bir meslekte beş yll geçirmiş, yoksulluk çekmiş, başarısızlık hissini yaşamış otoriteye karşı nefreti artarak toplumsal sınıfların varlığının farkına varmıştır. Kendi yüzyılında tanık olduğu savaşlar, toplumsal olaylar ve bireyin toplumsal yapı içindeki görünümleri, yazarı totalitarizme karşı durarak kendi ifadesiyle demokratik sosyalizmi destekleyen yazılar yazmaya yöneltmiştir (Orwell, 2017, s:12).Yazar, Hayvan Çiftliği adlı yapıtını değerlendirirken politik ve sanatsal amaçları bir bütünde kaynaştırmayı denediğini ifade eder ve çok da arzulamadığı halde kişisel yazma dürtüsünün sadece toplum yararına odaklanmış olduğunu belirtir. Politik amaçtan bağımsız yazdığı metinlerini de ruhsuzlukla itham eder (Orwell, 2017, s:15).

Mehmet Kaplan, Alain’in 'peşin fikirler sanat için öldürücüdür' görüşünden hareketle sanatçının hayat ve insanlarla, yeni karşılaşıyormuş gibi doğrudan doğruya temasının gerekliliğini vurguladığını söyleyerek ideolojinin, sanatçı ile gerçek arasında bir perde gerdiğini hem kendisi hem hayatı hür, ve taze bir ruhla kavramasina engel olur der (Kaplan, 1978, s:220). Kaplan, Orhan Kemal'den hareketle sosyal gerçekçilik esasına dayanarak edebi ürünlerini kaleme alan hikâyecilerin, hayat ve insanlar karşısında kendilerini hür hissetmedikleri, her şeyi dar ve yeknesak bir doktrine sokmaya çalıştıkları, onun dışında bir gerçek tanımadıkları için hep aynı tarz ve üslupta hikâyeler yazdıklarını vurgular. Kendi davalarını, klişeleşen hayat görüşü ve sanat tarzının zamanla okuyucunun ilgisini çekmemeye başlayacağı gerçeğinden hareketle öldürdüklerinin altını çizer (Kaplan, 1978, s:220).

Edebî ürünlerin toplumu savunma ve sanatçının idealize toplum anlayışı doğrultusunda mevcut siyasî düzeni eleştirme eğilimi edebiyatın, sosyolojinin, estetiğin meselesi olarak tarihsel bir görünüme sahip olduğu gibi düşünsel temelleri de çeşitli disiplinlerin ortaklığında şekillenmiştir. Görüşler fikir adamları ve edebiyatçıların perspektifince çeşitli yönleri ile ele alınabileceği gibi eserin siyasi ve toplumsal düzeni eleştiren niteliğinin sınırları da tartışlagelen mesele olarak konumlanmıştır. Batılı kaynaklarda izleri sürülebilen konunun Türk toplumu açısından edebiyatçı ve rejim eleştirisi niteliğine ilişkin görüşlerin de toplumun geçtiği tarihsel süreçte nüanslar içerdiği dikkati çeker.

\section{Türk edebiyatında sanatçının eser aracılığı ile toplumsalı ifadesi ve rejim eleștirisi}

Bir sanatçının toplumsal bağlanması, tutum ve ideolojisi, yalnızca yazdıklarıyla değil, çoğu zaman kendisiyle ilgili yazı dışı yaşam öyküsel belgeler yoluyla da incelenebilir. Yazar bir yurttaştır, toplumsal siyasal önem taşıyan konularda görüşlerini dile getirmiştir. Zamanın toplumsal olaylarına katılmıştır. Ancak yazarlar arasında toplumsal süreçle bütünleşme farklılıklar gösterebilir halk yazının da 
bütünleşme tam olarak gözlemlenebilirken (Wellek-Waren, 1982, s:131) sanat için ve estetik kaygıyı toplumsalın önünde tutan yazarda toplumdan kopuş daha çok gözlemlenebilir. Türk edebiyatı, siyasî tarih ve toplumsal yapı etkileşimi bağlamında dönüşümler göz önünde bulundurularak yazar kimliği ile sanatçının toplumsal süreçle bütünleşmesi, ideolojik eserlerin incelenmesi hem edebiyatın hem sosyolojinin ortak konusudur. Bu ortak alanın ortak kuramsal çerçevesinde ele alınan sanatçının ve yapıtın incelenmesinde temel ilke yazar ve toplum arasındaki karşılıklı etkileşim ve biçimlendirme unsurudur.

Max Weber'in ideal toplumsal tipler kavramından yararlanarak sinıfsal nefret, sonradan görme davranışları, züppelik gibi toplumsal olguları inceleyen Bramstedt, belli toplumsal tiplerle bunların davranışlarının romanlarda yeniden yaratılıp yaratılmadığını ne ölçüde yeniden yaratıldığını ancak bir toplumun yapısı konusunda salt yazınsal kaynakların dışındaki kaynaklardan bilgi edinen kişi bulup çıkarabilir der (Wellek-Waren, 1982, s:136). Romanın kaleme alındığı dönemdeki toplumsal koşulların ve tarihsel olguların romanın topluma ayna olması ya da toplumun romanı biçimlendirmesi ilişkisinde sadece edebiyat kuramlarının sunduğu imkânların değil toplumbilimin veri toplama ve analiz etme özelliğinin de etkili olacağı gerçektir. Bu anlamda edebi esere, Türk toplumunun gündelik hayat görünümleri ya da Türk siyasi yapısının toplumu biçimlendirişi nasıl yansımıştır noktasında yazarın toplum ve iktidarla etkileşimi izi sürülmesi gereken noktalardan biridir. Edebiyat tarihinde yazarların ve ya şairlerin eserleri hakkında kaleme aldıkları yazılarda, fikir yazılarında, mektup ya da hatıralarında ideolojik tutumları ya da mevcut siyasal rejimin toplum-sanat etkileşiminde sanatçının yapıtını nasıl etkilediği noktasında bilgiler edinmek mümkündür. Bunun yanı sıra edebiyat tarihçilerinin yaptığı çalışmalarda bu etkileşimi gün yüzüne çıarmıştır. Bu anlamda yazar ve şairlerin kendi Osmanlı döneminden itibaren yaşanılan siyasal süreçte ve bu sürece bağlı meydana gelen toplumsal yapıdaki değişimlerde toplumla yakınlaşma veya uzaklaşmalarında ideolojilerinin ve kimliklerinin etkisi olduğunu bu konuda yapılmış çeşitli çalışmaların ışığında söylemek mümkündür.

Sanatçının toplumsalı algılaması merkezinde Orhan Veli Kanık, Garip akımının poetik tutumunun çıkış noktası ile ilgili bir röportajında sanatın sanat olmak şartı ile her şey gibi cemiyet için olduğunu ifade eder ki, Orhan Okay'a göre sanatta ferdiyetçilikle, cemiyetçiliğin sentezidir (Okay, 2001, s:66). "Halk içinde yaşayan insanın ferdî olabileceğini sanmıyorum” diyen şair, bireyin en özel halinin dahi ona toplumdan yansıdığını belirtir. Sanattan fayda ummak noktasında "kim için?” sorusunu soran şair, sanat eserinden beklenen faydanın birey için değil, kalabalıklar ve toplum için olduğunu vurgular (Okay, 2001, s:67). Türk Edebiyatı tarihine bakıldığında toplum- edebiyat ve tarih ekseninde toplumun içinden geçtiği politik süreçlerin şairleri ve yazarları düşündürdüğünü ve bu bağlamda toplum yararına, toplumu savunmak gerek ilkesi ile yazdıklarını görmek mümkündür. Politikacı olup aynı zamanda edebiyat adamı kimliği olan ya da bir görüşün eleştirisini yaparken bir başka görüşün propagandasını yapan şairler ve yazarlar kendi dönemlerinin eleştirmenlerinin ya da edebiyatçlarının meselesine dönüşmüştür. Bu minvalde Necip Fazıl Kısakürek’in, aralıklarla otuzbeş yıl varlığını sürdüren Büyük Doğu dergisinin İdeolocya Örgüsü sütununda İslamî ve millî bir temele dayandırmak istediği ideal Türk cemiyetinin yapısını ve düzenini ayrıntılı şekilde ve çok defa kategorik olarak anlattığı fikir yazıları kaleme almıştır (Okay, 2001, s: 135). Dergi, rejimle karşı karşıya gelişlerinde kapatılmış daha sonra tekrar açılmıştır. İdeolocya Örgüsü köşesinde yer alan yazılar derginin her açılışında yeniden basılmıştır. Bu durumun sebebinin yeni nesillerin fikrin etrafında toplanması için kamuoyu oluşturmak ve Necip Fazıl'ın ütopyasını destekleyenlerin inancını pekiştirmek olduğunu söylemek mümkündür. Ancak Necip Fazıl'ın fikir yazılarındaki istikrarlı ve rijit politik tavır, şiir söz konusu olduğunda sanat ve estetiğe bağlılık noktasındaki istikrarı dikkati çeker. Ağaç dergisinde Manzara (Okay, 2001, s:143) başlığı ile kaleme aldığı yedi makalede Türk sanatkâr ve entelektüelini değerlendiren Necip Fazıl, 
sanatta ferdiyetçiliğin ustaları gördüğü Divan şairlerinin, toplumun inanç, meziyet, felsefe ve yaşam tarzlarını yansıttıklarını belirtir. Okay, Necip Fazıl'ın ilk olarak fikirlerini aktardığı yazılardan itibaren yaşamı boyunca sanatkârın, hem ferdi hem de sosyal olmasının kaçınılmaz olduğu konusundaki görüşlerini koruduğunu ifade eder (Okay, 2001, s:197).

Türk siyasî hayatının günümüze kadar toplumsal yapı üzerindeki tesirleri itibarılya en çok tartışllan dönemi olan tek parti dönemi sosyolog, siyasetçi ve edebiyat tarihçilerinin günceli anlamak üzere odaklandığı bir süreçtir. Tek parti döneminde, rejimden farklı ideolojik fikirleri olup rejim eleştirisi yapmak yoluyla zihnindeki toplum idealinden söz eden toplumcu gerçekçi yazar Sabahattin Ali'nin, sanatın ne olduğu ve edebi eserin amacı konusunda söyledikleri sanatı daha iyi bir toplumsal düzen için araç olarak gördüğünün ispatıdır.

Sabahattin Ali, "Benim kanaatimce sanat insana, insanı ve hayatı ve bunlarm manasinı öğretmekle muvazzaftrr. Ancak bu takdirde geniş kütlede daha çok insani olmak, daha iyi hayata varmak arzuları belirir. (...)Sanat bütün teferruatiyle hayatı ihtiva etmeli, insanda yaşamak, insan gibi yaşamak arzusunu hatta ihtiyacm uyandırmalıdır. Hülasa sanat, gaye değil vasıtadır. Gaye hayattır". (Şenderin, 1996, s:33) derken sanatı, sanatçının politik bağları ekseninde topluma insanca yaşamayı göstermekle yükümlü tutar. Sanatçının eseri aracılığı ile politik eleştiri yapmasını haklılaştıran bu görüssle de yetinmeyerek toplumsal fayda esasına bağlı olarak sanat, sanat içindir görüşündeki seçkin, halktan yabancılaşmış zümreden sanatı, "Bence hayattaki her şey gibi edebiyatta bir hizmet ve bir mücadeledir. Ve (...) daha doğruya, daha iyiye, daha güzele götüren bir mücadele, hiçbir zaman yüksek ruhlu bay üdebanın gönül eğlencesi değildir!" (Şenderin, 1996, s:33) diyerek soyutlar. Edebiyatı bir propaganda aracı olarak gören Sabahattin Ali, bu görüşünü ve gerekçelerini şu şekilde ifade eder:

"Edebiyat hatta alelumum sanat bence sanatkârın düşündüğü ve duyduğu bir fikrin ve bir hissin ortaya atılması, tamim edilmesi demektir; yani bir nevi propagandadır. Ben hiçbir zaman sanatın maksatsız olduğuna kâni olmadım . Bu takdirde de endividüalizmden mümkün olduğu kadar hayata, muhite dönmek, muhitten birçok şeyler almak ve muhite birçok şeyler vererek yazmak lazımdır. Bunun yapılabilmesinin birinci şartı ise muharrire realist olmak müsaadesinin verilmesidir" (Şenderin, 1996, s:34)

Bu noktada dikkati çeken bir diğer ayrıntı ise bireysellikten kurtulmuş sanatçının toplumda kanaat önderliği yapabilmesi için özgürleşmesi gereğini savunuyor oluşudur.

Nurettin Topçu ise felsefe ve sosyoloji konusundaki kuramsal bilgisi ile milliyetçi-muhafazakâr çizgideki ideolojik görüşünü doğu-batı mukayeseli olarak fikir eserlerinde ele almıştır. Görüşünün kuramsal temellerinden hareketle bir gençlik hareketi olan 'Anadoluculuk' fikrinin bir anlamda propagandası içinse hikâyenin kitlelere ulaşma yetisinden faydalanmıştır. Topçu sanatın ve sanatçının milli kültüre yabancılaşmasının karşısında muhafazakârdır. Batı’nın kendi kültürünü özümsemiş olmasından ve toplumsal ilerlemede bir anlamda sanatı yüksek kültür inşasının unsuru görmesinden hareketle yerelin durumunu tartışan Topçu sanatların ilerlemesi ve topluma yön vermesi ile rejim arasındaki ilişkiyi şu şekilde ele alır:

“Rönesans’ta, İtalya'da Papalık hükümetinin güzel sanatları himaye etmesi ile resimle heykel ve mimarlık gibi plastik sanatlarda pek büyük ilerleme olmuştur. Bizde Divan Edebiyatı'nın vücudu, ancak Saray ve onun etrafa yaydığı yasayış tarzı ile açıklanabilir. Sanatın rejimlerle ilgisi araştırılırken, bir kaide halinde şu fikri ileri sürebiliriz: Monarşik rejimlerde klasik kaideci sanatlar ilerliyor; demokrasilerde ise sanatın, kaideleri çiğneyerek ferdileşmeye doğru gittiğini görüyoruz. Asrımızda Komünist rejimle idare edilen yerlerde güzel sanatlar devletleşince sanatkârın hürriyeti elinden alındı. Sanat idealinin hür olarak fertlerden alınıp devlete mal edilmesi, sanatı yeknesaklığa düşürdü ve verimsiz hale getirmiştir.” (Topçu, 2001, s:185) 
Topçu, sosyolojik olarak sanatın, toplumsal yapı ve üretim biçiminin değişmesi ile sanat akımları haline dönüşerek sınırları aşıp yayıldığını belirtir. Sanayileşmenin sonucu olarak ortaya çıkan işçi sınıfının gündelik hayat görünümlerini anlatan toplumcu gerçeklik anlayışı ekseninde sosyalist görüş çevresinde şekillenen sanatların sıradan insanı görünür kılması üzerinde durduğu görüşleri şu şekildedir:

"İlkel cemiyetlerde hasat dolayısıyla yapılan dinî merasimlerde dans edilir ve şarkılar söylenirdi. Rönesans'ta sanatların pek ileri evrimlerinin önemli bir sebebi, cemiyette burjuva denilen büyük zenginlerin çok bulunması ve bunların kendi zevklerini eser halinde ortaya koyabilecek sanatkârları himaye etmeleri olmuştur. Bugün büyük sanat hareketleri hep ekonomik bakımdan büyük şehirlerde merkezileşiyor. Taşıtların artması ve yeni kıtaların keşfolunması, sanatları millet sınırlarının dışına çıarıyor, milletlerarası zevklerin doğması kabil oluyor. Zevkler genişliyor; yeni sanat şekilleri doğuyor. Mesela sinemacılık Amerika'dan bütün dünyaya yayılarak yeni duyuş tarzlarını her millete aşılıyor. Geçen asırda Avrupa'da doğan büyük sanayi, işçi sınıfını meydana çıkardı. Bu sınıfın hayatını anlatan ve duygularını nakleden realist ve sosyalist sanatlar doğdu. Eskiden klâsik edebiyatın kahramanları, krallar ve prensler gibi yüksek sınıfların insanları idi; bugünkü romanlarda hep basit insanların, aşağı tabaka adamlarının hayatları anlatılmaktadır. Bu sanatta üslup dahi değişiyor; halkın tabii konuşma dili sanat eserine giriyor.” (Topçu, 2001, s:186)

Topçu durumun yerli edebiyata yansıması hakkındaki görüşünü de "Servet-i Fünûn edebiyatı bir burjuva edebiyat idi; yakn yıllarda yazılan roman ve hikâyelerimize ise, halkn ve köylünün hayat ve ifade şekilleri girebilmiştir" diyerek açılar. Türkiye'nin Maarif Davası adlı eserinde ise Topçu, kitleleri etkileme ve toplumsal hayatı dönüştürme kabiliyeti olan edebiyatın toplumsal yapı üzerindeki etkisini yabancılaşma bir anlamda kültürel yozlaşma olarak görür ve düşüncelerini sanatın toplumu olumsuz değiştirmesi perspektifinden şu şekilde ifade eder:

"Mâi ve Siyah romanındaki Ahmet Cemil'in hasta varlı̆̆ı, bir iman buhranının kurbanıdır. Onda artık ne Bedr'in aslanlarından, ne de Alpaslan'ın âleme rahmet taşıran ruhundan bir damla kalmıştır. Bu nesil, kendini inkâr ederek Batı'ya çevrilmek isterken, materyalizmin ve pozitivizmin çorak zemininde kendi kurbanlarını vermiştir. Yokluğuna inanmak için kendini zorlayan varlık, kendinden hakikate doğru yürümek kudretsizliğini duyunca, bizzat kendinin inkârında kurtuluşunu aradı. Fikret'in, tablosunu çizdiği yeis ve hüsran karanlığı içinde yetişen Baha Tevfik ve Ahmet Nebil gibi genç düşünürler, maddenin kendi kendisine yeterli oluşuna inanmak için zekâlarını zorlarken, Beşir Fuat genç yasında intihar etti. Bu zavallılar, aklın tıkandığı bir çıkmazda buhran içinde yasamayı, hakikatler semasında uçmaya tercih eden, iradesinin iktidarı tükenmiş bir gençliğin bedbaht önderleri oldular (Topçu, 2006, ss:19-20).

Nurettin Topçu, edebiyatın ve edebiyatçının toplumsalı toplumsal gerçekçilik bakış açısıyla ele alma biçimini, toplumu ileri götürecek idealist tutumdan yoksunluk ve sıradanlaşma eğiliminde olmakla şu şekilde yargılar:

"Âkifin aşlmaz, erişilmez büyük hüviyetini bir tarafa bırakıyorum, bugün Rıza Tevfik ile Faruk Nafiz'i ve Orhan Seyfi'yi bile unutturacak bir şairin, Refik Halid'le Ömer Seyfettin'i çlgın tahassürle aratmayacak bir hikâyecimizin varlığını düşünmenin bir hayal olduğunu görüyorum. Yeni şiir bir saylklama, roman ve hikâye bayağı tahkiyeden ibaret olmuştur. Bunlar ruhu yeni dünyalara götürmüyor, insanı yeni doğuşlara kavuşturmuyorlar. Bunlarda yıpranmış bir toplum davasından öte ne bir felsefe, ne de büyük sanat kokusu var. İnsan hayatının değeri ve mukadderatımız meselesi sanatın ana davası olduğu halde, son devrin sanatı insanla ilgisizdir. Eserde sanatkârın kalbi yok, cemiyetin yumruğu görülüyor. Mükemmel lakin alelade bir eşkıya hikâyesinden başka bir şey olmayan İnce Memed'i Memleket Hikâyeleri ile karşılaştırmak edebiyatımızın yarım asırda yuvarlandığı uçurumu göstermeye kâfidir” (Topçu, 2004, s:202).

Topçu'ya göre, sanat, insanı ele alırken sanatçının duygusu ve sanatın felsefik temelleri önemlidir ve sadece toplumsal gerçekçilik esası ile ele alınan toplumsal yapı-siyaset ilişkisine dayalı eser sıradanlaşmaya mahkûmdur. 
Ömer Faruk Akün, fikir adamı ve araştırıcı olduğu kadar onlarla birlikte yürüyen edebiyatçı şahsiyeti

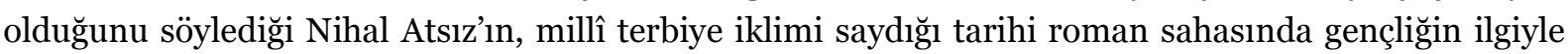
takip ettiği tarihi romanlarından söz eder. Akün, gerçek anlamda tarihî roman olmayan Dalkavuklar Gecesinnin Cumhuriyet devrinin ilk onbeş yılını eleştirdiği siyasi hiciv niteliği taşıdığını belirtir (Akün, 1991, s:288). Atsız, Türkçülük fikrinin ışığında fikir yazıları, romanlar, öyküler ve şiirler yazarken döneminde Nazım Hikmet ve Sabahattin Ali’nin ideolojik görüşlerini ve ideolojik görüşlerinin eserlerine yansımasını eleştirmiştir (Atsız, 1992).

Yakup Kadri Karaosmanoğlu da sanatın amacı ile ilgili görüşlerinde, "Sanatın gayesi, (eğer mutlaka bir gaye bulmak lâzım ise),bence bir kavmi, bir milleti hissetmeye, iyi hissetmeye, büyük hissetmeye alş̧tırmasıdır .Çünkü hissetmesini bilmeyen kavimler, yaşamasın bilmezler, ayn bizim gibi...ve yaşamasın bilmeyen bir kavme,ulum-ı içtimaiyyeden bahsetmek bana biraz abes görünür. Bu tamamıyla bir topala veya henüz yürümeye başlamış bir çocuğa raks usulleri talim etmeye benzer" (Büyükarman, 2002, s:14) diyerek sanatın toplumsal işlevini millet olarak hissetmek ve millî şuurun teşekkülü için gereklilik olarak tanımlar. İşgal İstanbul'unda İkdam gazetesinde Anadolu hareketini öven yazıları sürdürebilmek hem İstanbul hükümetinin hem de işgalcilerin sansürünü bertaraf etmek için küȩük hikâye başlığı kullandığını belirten Yakup Kadri, özellikle edebiyatta milliyetçi bir tutumla eserlerini kaleme almıştır. Ancak yazar, millî edebiyatın artık kahramanlık destanlarından ibaret şiirlerin ötesinde millî estetik anlayışı ile eser verilmesi gereğini belirtirken millî edebiyat, musiki, resim adına yapılanların hamasete boğulduğunda sunilikten öteye geçemeyeceğini bir anlamda propagandist tavrın emperyalizm ile milliyetçilik fikrinin karıştırılmasından kaynaklı olduğunu ifade eder (Büyükarman, 2002, s:31).

Fikir adamı, siyasetçi ve edebiyatçı kimlikleri ile toplumsal yapıda siyaset eliyle meydana gelen değiş̧ikliklerin tanıklığını yapan edebiyatçılar kendi ideolojileri ve bağlanmaları doğrultusunda sistemin eleştirisi yapan eserler kaleme almışlardır. Hepsini bu tutumda birleştiren nokta daha iyi bir toplumun inşası idealidir. Ancak edebi eserin gayesi noktasında zaman zaman ideolojik fikir yazıları olmasına rağmen sanatın sanat için yapılması gerektiğini estetik kaidelere bağlılığı savunan edebiyatçılar da olduğu gerçektir. Ancak hangi ideolojik görüşe sahip olursa olsun edebiyatçı toplumu savunmuş ve bunu kendi estetik anlayışı ile gerçekleştirmiştir. Rejimin tutumuna bağlı olarak toplumu savunmak üzere bazen siyasî idareyi gerçekçi tutumla eleştiren ve sosyolojik unsurlar içeren eserler verebilmişlerse de ütopyalarını zaman zaman alegorik eleştirinin olanakları ile kitlelerle buluşturmuşlardır.

\section{Edebî eserler aracılığı ile tek parti dönemi siyasal ve sosyal koşullarının eleştirisi: Çalgıčlar, Sırça Köşk, Dalkavuklar Gecesi ve Ankara}

Heyet-i Temsiliye' nin Ankara’ya gelmesi ile beraber Millî Mücadele'de fiilen başkent olan Ankara 13 Ekim 1923'te resmen ülkenin yönetim merkezi olmuştu. Onaltı gün sonra Cumhuriyet’in ilanı ile beraber rejim değişikliği de gündeme gelince Ankara, yeni rejimin kendisini her bakımdan hem ülkeye hem de bütün dünyaya kabul ettirmek amacı ile bir vitrine dönüşmüştü.

Bir Orta Anadolu kenti olan şehir bir yandan planlama hareketleri ve elektrikle ev ve sokakların aydınlatılması, yeni ve geniş yolların açılması, yerleşim yerlerine su getirilmesi, yeşil alanların oluşturulması ile çağdaş bir görünüme kavuşturulmaya çalışılırken bir yandan da rejimin yaptığı yenilik hareketlerinin halka ve elçilik ve iş görüşmeleri için şehirde bulunan Batılı gazeteci ve iş adamları ile vasitasıyla tüm dünyaya, kültürel ve ekonomik etkinlikler ve sosyal yaşamdaki değişiklikler ile duyurulmaya, gösterilmeye çalışılıyordu 
$\mathrm{Bu}$ durum devlete 450 yıldan fazla başkentlik yapmış İstanbul ile Ankara arasında her bakımdan bir çekişmenin gündeme gelmesine doğal olarak yol açıyordu. Bugün hâlâ tartışmaları süren İstanbul'un kültürel ve ekonomik başkent oluşu, Ankara'nın sadece bir yönetim merkezinden ve taşradan ibaret kalması düşüncesinin temelleri o günden atılmış ve özellikle İstanbul basını, entelektüel ve akademik çevreler yeni başkenti kâle almayıp hatta zaman zaman küçük görerek yok varsaydıkça yeni rejim, bu rejimin destekçileri ve Ankara daha gösterişli bir biçimde yenilikler yapmış ve yeni devletin düşünceleri kendisini bu şehirde göstermişti.

İşin tarihî ve siyasî boyutları bir kenara bırakıldığında gazeteci/yazar sınıfının İstanbul ve dolayısı ile muhalif bölümü zaman zaman bu yeni Ankara'nın/başkentin yeniliklerine ve orada oluşan yeni hayat tarzına yazdıkları eserlerle eleştirilerde bulunmuşlardır. Türkiye'de 1950'ye kadar süren tek-parti (Cumhuriyet Halk Partisi) iktidarı döneminde hem bu tek partiye ve onun uygulamalarına muhalif olan yazarlar hem de Parti mensubu ya da sempatizanı olan yazarlar da eleştirilerde bulunmuşlardır.

$\mathrm{Bu}$ eleştirilerin parti mensubu ya da sempatizalarınca yapılan bölümü ağırlıklı olarak "üst yönetim tarafından yapılan yenilik ve inkılâpların doğru anlaşılıp yorumlanmadığına, bazı kısımlarının eksik bırakıldığına ve geniş halk kitlelerine yeterince açık anlatılamadığı için bu kitleler tarafından yabancılıkla karşılandığına” dairdir. Tek-Parti yönetiminde özellikle 1946'da çok partili hayata geçinceye kadar Cumhuriyet Halk Partisi mensubu ya da sempatizanı olan yazarlar için bu durumun bu şekilde karşılanması ve aktarılması tabiidir.

Muhalif olanlar herhangi bir parti ya da sivil toplum örgütü kurarak düşüncelerini dile getirecekleri ortam ve imkân bulamadıklarından onlar da edebiyatçı yönleri ile ve genel olarak alegorik, sembolik bir biçimde düşüncelerini ortaya koymuşlardır.

Burada ilk önce bu alegorik/sembolik yöntemle kaleme alınan üç eleştirel hikaye ele alınacaktır. Bunlardan ilk ikisi tamamen alegorik olup hikayelerde herhangi bir isim ya da yer belirtilmez ancak yazanların muhalif kişiliğinden ve hikayelerin içeriğinden anlatılanların yeni Ankara ve eleştirilenin bu yeni rejim olduğu ortaya çıar. Bunlar Nurettin Topçu'nun Çalgıcılar ve Sabahattin Ali’nin Strça Köşk isimli kısa hikâyeleridir.

Milliyetçi ve muhafazakâr kimliği ile tanınan Nurettin Topçu (1909-1975) 1939'da Hareket dergisinde Nizam Ahmed müstearıyla yayımladığı Çalgıcılar'da (Topçu, 1998, ss:293-295) tamamen soyut bir atmosfer çizer. Buna göre "çalgıcılar toplanır ve önce iğreti oturdukları sandalyelerine daha sonra hakiki sahipleri imiş gibi kurulurlar”. Zaman geçtikçe çalgıcılar ellerindeki aletlerle ses çıkarmaya başlar ve bu seslerin şiddeti arttıkça etraftan başka ses duyulmaz olur. Çalgıcılar çok kısa zamanda -uzaktaki ağacın altında oturan bir kişi hariç- "herkesi mest ederler". Ağacın altında oturan kişi çalgıcılar ve çıkardıkları sesler olmasa bir "tatlı sükûn yaşanacağını, kuşların seslerinin duyulacağını ve tabiattaki hürriyetin hissedileceğini” söyler. Bu esnada çalgıcılar bir yanda yiyip içmekte ve çevredeki insanlar onları alkışladıkça çalgılarını çalmaya ve yiyip içmeye devam etmektedirler. Bu çalgıcılar, dinleyenlerin içinde yer alan ve kendisi de eğlenceye iştirak eden bir kişi tarafından idare edilmektedir. Çalgıcıları besleyen, onları yedirip içiren, ne zaman çalıp ne zaman duracaklarını söyleyen hep bu kişidir ve bu âhenk/düzen onun emri ile kurulmuştur. O "hangi havayı isterse çalgıcılar o havadan" çalmaktadır. İdare eden kişi ne kadar kötü bir müzik çaldırırsa çaldırsın, çalgıcılar onu her halükârda övüp, dinleyenler ise alkışlarken bir kısmı ise "kulluk eder derecede övücü cümleler" kurarlar. Bir süre sonra ağacın altında oturan adam bu duruma daha fazla dayanamaz ve ayağa kalkarak şöyle bağırır: "Çalınan havalar en bozuk en iğrenç nağmelerdir. Çalgıcıları susturun, tabiattaki sesleri dinleyelim; hakiki sesler onlardır. Bu ağaçta bülbül 
ötüyor, yanımızda bir dere çağıldıyor. Bir kere dinleyin gerçek sesler bunlardır. Susturun bu çalgıcıları. Susturun onları”. Ancak bu çıkış çalgıcıların ve dinleyenlerin ağacın altında oturan adamın üzerine atılıp onu uzaklaştırmaları ile son bulur.

Bu kısa alegorik hikâyenin yazıldığı dönemde Türkiye'de tek parti sistemi devam etmektedir. Dolayısı ile rejimin ve rejimin yanlış uygulamalarının eleştirisi ancak soyut ve alegorik bir biçimde yapılabilmektedir. Hikâyede emir veren kendisine dalkavukluk edilmesinden hoşlanan kişi üst yönetimi, çalgıcılar rejimin bürokratlarını, dinleyenler ise rejimin işleyişinden nemalanan ve dolayısı ile hem üst yönetime hem de bürokratlara dalkavukluk eden küȩük, fakat nemalanmaktan mutlu bir sınıfı temsil etmektedir. Ağacın altında oturan adam ise halkın menfaatini, hürriyeti ve insanın normal hayat akışına uygun olan bir rejimi özleyen aydın ve akil tavrı benimsemiş görüşü yansıtmaktadır. Bu muhalif tavır bütün tek parti sistemlerinde olduğu gibi hoş karşılanmamış ve topluluğun dışına atılmıştır.

Sosyalist görüşleriyle bilinen ve tek parti yönetiminde başı sürekli olarak mahkemelerle ve polisle derde giren Sabahattin Ali (1907-1948) Sirça Köşk masalında/hikâyesinde olaya başka bir açıdan yaklaşır (Ali, 1947, ss:138-143). Hikâyenin başlangıcında boş gezmeyi seven üç arkadaş bir gün bilmedikleri bir şehre gelip orada kendi hâlinde mutlu ve kanaatkâr bir biçimde yaşayan insanlara şehirde bir sırça köşk olup olmadıklarını sorarlar. Olumsuz cevap aldıkça hayrete ve dehşete düşerek halkı kandırırlar ve mutlaka bir sırça köşklerinin olması yönünde ahaliyi ikna ederler. Nihayet halk bütün masrafları kendilerine ait olmak kaydı ile üç arkadaşı da mimar yaparak bir sırça köşk inşa etmeye karar verir. Bir katın inşaatı bitince üç arkadaş sırça köşk'e yerleşirler. Bunu az bulan üç arkadaş bir kat daha çlkmak isterler. Bunun için yeni işçiler yeni masraf lazımdır. Bina büyüdükçe burada oturanların sayısı ve dolayısı ile masraflar da artmaya başlamıştır. Üç arkadaş halkın arasından kendileri ile işbirliği yapacak insanları bulup onları da köşke yerleştirdikçe bina büyümeye insan sayısı ve dolayısı ile masraf artmaya başlar. Artık halkın Sırça Köşk'ün masraflarına ayıracak parası ve orada besledikleri insanların eğlenceli sefahat içindeki hayatlarına tahammülleri kalmadığından bir gün isyan ederek durumu sorgularlar. Üç arkadaşın elebaşı, köşkte yaşayan insanların görevlerini "Sırça Kök'e girip çıanların adlarını yazmak, malları saymak, halktan mal göndermeyenleri bulmak, halka Köşk'ü süpürtmek, ışıkçı başılık, döşekçi başllık, döşekçibaşı yamaklı̆̆ı, döşekçibaşı yamak yamaklığı” gibi aslında mevcudiyetine hiç gerek olmayan işler, sıralar ve bu görevler olmadığında halkın da var olmayacağını ikna eder. Nihayetinde halk Sırça Köşk varlığını sürdürdükçe onun hizmetine bakanların, sonra bu hizmete bakanların hizmetine bakanların varlığına ikna olmuştur. Ama sonunda Sırça Köşk o kadar büyümüştür ki Köşk’ün adamları bir gün gelip halkın yiyecek ve giyeceğini zorla almıştır. Köşk’ün yıkılması gereğini iddia eden halk da işkence ile bezdirilmiştir. Halkın elindeki son koyunları da alan Köşk yönetimi koyunların başlarını halka tekrar geri dağıtınca sinirlenen bir kişi kelleyi Köşk'e firlatır ve bu kelle Köşk’te bir gedik açar. "Halk her şeyden sağlam, hiç bir zaman yıkılmaz kırılmaz bildiği o koskoca sırça köşkün bu kadar çürük olduğunu görünce elindeki kelleleri birbiri arkasına ona fırlatmaya başlamış, göz açıp kapayıncaya kadar tuzla buz olan köşk çökmüş, yıkılmış, içindekilerin çoğu cam kırıklarının altında ezilmiştir.” Bunun ardından şehirde ihtiyarlar çocuklara şu ögüdü verir olmuştur: "Sakın tepenize bir sırça köşk kurmayınız. Ama günün birinde nasılsa böyle bir sırça köşk kurulursa onun yıkılmaz, devrilmez bir şey olduğunu sanmayın. En heybetlisini tuzla buz etmek için üç beş kelle firlatmak yeter”.

Sabahattin Ali'nin bu masalda/hikâyede Almanya'yı sembolize ettiğine dair görüşler (Boyacı, 1982, s:104) var olsa da yazar burada bir tek parti rejiminin eleştirisini yapmaktadır. Ve başı sürekli olarak bu rejimle derde giren, bu sebeple geçim sıkıntısı çeken, mahkemelere çıkıp hapislere düşen ve takibata uğrayan yazarın kendi bakış açısı ile o dönemin bir takım uygulamalarını tenkit ettiği de muhakkaktır. (Nitekim kitap yayınlandığı zaman toplatılması, rejimin bu alegoriyi üzerine aldığını göstermektedir). 
(BOA: 52-59). Buna göre halkı bir şekilde ikna edip kendilerine hizmet için onları kullanan üst yönetim, kendilerine bir sırça köşk yaparlar ve orada halktan tamamen kopuk zevk ü safa içinde bir hayat sürmeye başlarlar. Bu hayatı sürdürebilmek için halktan bazı kişileri işbirlikçi olarak yanlarına alırlar ve böylece halkın üzerine binen yük giderek artar. Fakir halk fakir kalmaya devam ederken onların arasından çıkıp Sırça Köşk'e geçmeyi başaranlar o an geldikleri yeri unutup yeni hayatlarına adapte olmaktadırlar. Bu hayatın sürdürülebilmesi için de vergiler giderek artar ve zorbalık başlar. Bu zorbalık, halktan cesaret gösterip sesini yükselterek harekete geçen bir vatandaşın eylem başlatması ile son bulur. Sırça köşk yıkılır, zorbalık ve tasallut sona erer; Sırça Köşk’ten önceki hür ve mutlu günlere dönülür. Burada Sabahattin Ali'nin bakış açısı ile Sırça Köşk, Ankara'daki tek-parti yönetimini, Köşk'e doluşanlar yönetimle işbirliği içinde olup da halkın durumuna önem vermeyenleri sembolize etmektedir.

Üçüncü alegorik eleştiri ise milliyetçi/ırkçı görüşleriyle tanınan Nihal Atsı’’n (1905-1975) Dalkavuklar Gecesi başlıklı -diğerlerine oranla uzunca-hikâyesidir ki burada o dönemin Ankara'sının kişilikleri isimlerinin tersten yazılışı ile daha anlaşılabilir bir biçimdedir (Atsız, 1941). Üstelik burada Ankara'yı hatırlatması için de yine bir Orta Anadolu başkenti olan Hattuşaş kullanılmıştır. Hikâye Hatti'lerin başkenti Hattuşaş'ta geçer ve Kral Subbiluliyuma'dır. Sarayın mahzenlerinde bulunan ve öldürücü zehir olarak bilinen fiçılar dolusu bir sıvıdan bir gün bir kadın içer ve ölmediği gibi aksine gülerek rahat tavırlar takınır. Bunun üzerine Kral bir kurultay toplayarak hem kendi ülkesinden hem de çevre ülkelerden bilginleri bir araya getirir ve -şarap olduğu her hâlinden belli olan- bu sıvının "Tanrılardan kendi atalarına yadigâr edilmiş bir su” olduğunu ispatlamaları halinde kendilerine büyük ödüller verileceğini belirtir. Kurultaya gelen bütün bilginler durumun farkında oldukları halde "bilimsel!" olarak Kral'ın argümanını ispatlarlar ve mükâfatlandırılırlar. Üst yönetim ve bürokratlar bu işlerle ve yiyip içmekle uğraşırken ordu savaşa çıkar ve büyük kayıplarla bir zafer kazanarak döner. Bunu "kahramanlar gecesi” olarak kutlamak isteyen saray ileri gelenleri gene üç gün gece eğlenirler yerler içerler. Yöneticiler bürokratlar ahlâken de bir düşkünlük içindedir. Kimse kötülükleri, ahlâksızları görmek istemez. Herkes bu hayat sürsün diye çaba sarfeder. Sonunda bu gecenin "kahramanlar" değil bir "dalkavuklar gecesi" olduğunu belirtilmesi ile hikâye son bulur.

Dalkavuklar Gecesi’nde İlanasam: Hasan Âli Yücel, Rahip İduskam: Sadri Maksudi Arsal, Yaver Sabba: Cevat Abbas Gürer; Pilga: Reşid Galip, Baş Hekim Ziza: Şevket Aziz Kansu; Yeni Başhekim Teşen: Neşet Ömer İrdelp; Nibida: Abidin Özmen; Yamzu:Afet İnan; İkeznini: Zeki Velidi Togan; Kâhin Şilka: Hüseyin Nihal Atsız; Tubişka: Bedriye Atsız, Kahin Şilka'nın oğlu Murya, Yağmur Atsız'dır.

Yukarıda da belirtildiği gibi bu sembolik isimler ya gerçek isimlerin bire bir tersten okunuşudur ya da bu okunuşun benzer bir şeklidir. Hikayede bu tarz isimlendirmeye istisna teşkil eden kişiliklerden biri Başkomutan Tutaşil'dir bu kişi Fevzi Çakmak'ı sembolize etmektedir. Kral Subbiluliyuma'nın ise Atatürk’ü sembolize ettiğine dair görüşler vardır.

Dönemin Ankara'sını bir tür kara mizah anlayışı ile tasvir ve tenkit eden Nihal Atsız "kurultay" ve "tılsımlı su” ile bütün insanlığın Türklerden geldiğini öne süren Türk Tarih Tezi'ni ve bu tezi ispatlamak için toplanan Birinci Türk Tarih Kurultayı'nı anlatmıştır. Yine üst yönetime dalkavukluk ederek şiirler yazan, şarkılar besteleyen, övgüler düzen ve bu yolla elde ettiği hayat seviyesni sürdürmeye çalışan bir grup bürokratı kendi bakış açısı ile keskin bir biçimde eleştirmiştir.

Bu üç hikâyenin ortak yönleri olarak kurulu düzen içinde eğlence, karmaşa, keşmekeş, dans, müzik alkollü içki, yemekler, üst yönetime dalkavukluk ederek hayatı sürdürme, zaman zaman ahlâkî değerlerin ortadan kaybolması, değişik ve muhalif görüşlere hoşgörü ile bakılmaması gösterilebilir. 
$\mathrm{Bu}$ alegorik ve sembolik yaklaşımlardan sonra somut bir eleştiri örneği olarak ise Yakup Kadri Karaosmanoğlu'nun (1889-1974) Ankara isimli romanı verilebilir. Diğer üç kişinin aksine baştan beri yeni kurulan rejimle içiçe ve iktidardaki tek partinin, Cumhuriyet Halk Partisi'nin mensubu ve milletvekili olan ve yapılan yenilik ve inkılâpların hem benimseyeni hem de şiddetli savunucusu olan bir yazarın tenkitleri bu açıdan dikkate değerdir.

Ankara romanında şehrin Millî Mücadele, yeni rejimin ilk dönemi ve ikinci dönemini anlatan Yakup Kadri Karaosmanoğlu ilk iki dönemi içinde yaşadığı için kendi bakış açısı ile gerçekçi bir biçimde yansıtırken son dönemi kendi hayali ile kurgular (Karaosmanoğlu. 1934) Millî Mücadele döneminde İstanbul'dan eşinin görevli olduğu Ankara'ya gelen Selma Hanım burada çok ibtidai şartlar içinde yaşar. Bu kadar zor şartlar altında verilen bir kurtuluş mücadelesinde ve onun merkezi olan Ankara'da kimse halinden şikâyet etmemektedir. Ancak Selma'nın kocası Nazif, Yunan ordusunun ilerlemesi ile beraber karısını ve Ankara'yı terk eder. Romanın ikinci bölümünde Selma, ilk bölümde tanıştığı Binbaşı Hakkı Bey ile evlidir. İlk bölümde Avrupa ve onun sömürgeci anlayışı ile savaşan Binbaşı Hakkı Bey gitmiş yerine "miralaylıktan emekli" şirket yönetim kurulu azâsı Hakkı Bey gelmiştir. Bu bölümdeki Ankara'dan ve Ankaralılardan tiksinen Selma sonunda Hakkı'dan boşanır ve üçüncü bölümde genç, idealist ve yeni rejimi ve inkılâpları doğru algılayan gazeteci Neşet Sabit'le evlenir ve Ankara bütün çağdaşlığı ve modernliği ile bütün dünyanın özendiği bir yer olur.

Ankara'nın ikinci bölümünde Yakup Kadri’nin anlattıkları adeta diğer üç kısa hikâyede alegorik olarak anlatılanların somutlaştırılmış hâlidir. Romanın ilk bölümünde anlatılan Ankara'dan eser kalmamıştır. Binbaşı Hakkı, albaylıktan emekliye ayrılmış ve bir şirketin yönetim kuruluna girmiş, yabancı şirketlerin ihale alabilmesi için bakanlarla görüşme ayarlamaya ve bu işten "komisyon!” almaya çalışmaktadır.

Naziften boşanıp Hakkı ile evlenen Selma bütün gününü balolarda eğlencelerde oyunlarda geçirmektedir. Millî Mücadele'nin çok sayıda ismi de yine böyle bir hayat sürmektedir. Bu insanların hayatlarını diledikleri gibi sürdürebilmeleri için de kuleli, asansörlü, çok sayıda odası ve banyosu olan lüks malzemelerle yapılmış evlerden oluşan bir Yenişehir inşa edilmiş bunun yanında eski fakir Ankara da varlığını sürdürmeye devam etmiştir. (Yeni hayat şekli artık eskisine o kadar uzaktır ki bir ara Selma Hanım “Ankara'nın içi hâlâ o eski zamanlardaki gibi mi?” diye sorar.) Bu her bakımdan Yenişehir, yeni rejimin yaptığı yeniliklerin de ortaya konduğu ve o tarz bir hayatın sürdürüldüğü bir vitrin konumuna gelmiştir. Eski Ankara yine karanlıklar içinde iken Yenişehir'in hem evleri hem de sokakları gece sabaha kadar ışıl ışıl aydınlıktır. Yapılan savaştan sonra askerî olarak ülkeye giremeyen Avrupa, kültürü, dili, mimarisi, giyimi, sosyal hayatı ile bütün Ankara'yı adeta esir almıştır. Savaş yıllarında Avrupa düşmanı olan ve "Şunlara gâvur deyin. Avrupa medeniyeti Avrupalıların uydurduğu yüzbin yalandan biridir" diyen Hakkı, artık tamamen bir Avrupa'lı gibi yaşamakta ve bütün vaktini Ankara'daki Avrupalılara geçirmektedir." Selma'ya göre bu yaşanan yeni tarz hayat tamamen "snopluk"tur

Yeni hayatın göstergelerinden biri olan ve hemen her gün ve gece değişik evlerde verilen balolar ve bu balolarda sürekli olarak herkesin birbiri ile dans etmesi dikkat çekmektedir. Bu balolar için elbiseler ya da kumaşlar mutlaka Paris'ten ithal edilmekte ve bu hemen her balo için yeniden tekrarlanmaktadır. Eskiden ulaşım için at veya katır bulunmazken yeni rejimle içiçe olanlar artık diledikleri zaman otomobil bulabilmektedir. Müteahhitlik işleri ya da devletle ilgili işlerin kolaylaşması için komisyon almak adeta normal karşılanmaktadır. Türk kadınları kapalı bir giyim tarzında iken yeni hayatta böyle bir şey de söz konusu değildir. Hatta bir ara Selma'nın bu durumdan "Bizi yalnız süsleyip dans ettirmek için mi açtınız? Yalnız buna yarayan bir kadın hürriyetinin ne kıymeti var?” şeklinde yakınması üzerine kocası Hakkı Bey’in verdiği cevap kayda değerdir: “Geriye alırsak kıymetini o zaman anlarsınız!”. 
Ancak Yakup Kadri'ye göre Ankara'da yaşanan bu tarz hayatın üst yönetimle bir ilgisi yoktur. Bilakis bunlar Cumhuriyet’i kuran ve yenilikleri yapan kadronun doğru anlaşılamamasından/yanlış yorumlanmasından kaynaklanmaktadır. Yakup Kadri bu görüşlerini, romanın üęüncü bölümünde Selma'nın evleneceği Neşet Sabit’in ağzından şöyle dile getirir:

"Bunlar hep inkılâbın yanlış anlaşılmasından çıkan neticeler. İnkılabı kocanız kendine göre, Murat Bey kendine göre, Şeyh Emin kendine göre anlıyor; hani bazı dinler vardır ki müfessir ve müçtehidlerin çokluğu yüzünden mana ve mahiyetini değiştirir; işte bizim inkılâbımızın başına böyle bir şey gelmektedir”. Neşet Sabit bir başka yerde de -sürekli dans ederek yiyip içen eğlenen insanları göstererekşunları söylemektedir: "Garp medeniyeti Garp muaşereti diyoruz. Lakin Garp’ta da işte bu bizim beğenmediğimiz şeyler yapılıyor. Orada da hep bu havalardan bu danslardan başka ne var? Şimdi iyi kötü cereyana kapılmış bu insanların önüne çıkıp da 'Efendiler, Garpçılık bu demek değildir. Garpçılığı bir eğlence telakki etmeyiniz. Garpçllı her şeyden evvel bir yaratma, kurma, iletme ve işletme gücüdür. Bütün bu yaptığınız şeyler hep onlardan sonra gelir' diye bağıracak olsanız onların keyfini kaçırmaktan başka bir işe yaramaz”

İktidarın yanında ve karşısında konumlanmış, siyasetçi, eleştirmen, şair, yazar ve fikir adamı kimliklerine sahip sanatçılar, makalede ele alınan eserlerinde Tek Parti Dönemi'nin politik uygulamalarının ve sonuçlarının toplum üzerindeki ve bürokrasideki etkisini eleştirmiştir. Bu eserlerin kaleme alındığı dönemde sanatçının siyaseti yorumlayışı kadar siyasetçinin de sanatçıyı konumlayış ve algılayışı önemli göstergeler içerir. Tek Parti Dönemi siyaseti sanatçıyı politikalarının haklılaştırılması, kamuoyu oluşturma gibi süreçlerde yanında konumlandırırken, kamuoyunu sosyal yapının ve bürokrasinin değerler anlamında yozlaşması yönüyle yansıttığı zaman karşısında ve ideolojik görüşün aynası olarak yorumlar demek mümkündür.

\section{Sonuç}

Tek Parti Döneminde Yakup Kadri gibi partili olan ya da bir partiye mensup olmamakla beraber milliyetçi, muhafazakâr veya sosyalist görüşleri benimseyen farklı kimliklere sahip yazarlar siyasal görüşlerini edebî eserlerine yansıtmışlardır. Siyasi görüşlerinin yanında mevcut siyasi rejimin toplumsal yaşama etkisini de gündelik hayat görünümleri olarak eserlerine yansıtan sanatçılar, dönemin sosyal yapısını farklı sosyolojik değişkenlere bağlı olarak günümüz araştırmacıları için incelenebilir kılmışlardır. Bir anlamda sanatçının eseri kendi döneminin aynası olma niteliği kazanmıştır.

Türkiye'de tek parti döneminde (1923-1946) siyasi olarak örgütlenme imkânı bulamayan muhalefet, ancak alegorik/ sembolik yaklaşımlarla yazdıkları hikâye ve romanlarla rejimi ve iktidarı eleştirebilmişlerdir. İktidar partisi mensubu ya da sempatizanı olan edebiyatçılar ise rejimin yanlış ya da eksik buldukları uygulamalarını üst yönetime değil bu yenilikleri yanlış anlayanlara bağlama eğilimindedirler demek mümkündür. Ayrıca, çalışmanın genel olarak ortaya koyduğu bir başka sonuç ise siyasetin dönemsel karakteri ile sanatçıyı konumlandırışı ve sanata yaklaşımı arasındaki ilişkinin belirginliğidir. Sanatçının, iktidarın politik uygulamalarına yönelik eleştirilerini eserlerine alegorik ya da gerçek olarak yansıtması dönemin fikir sanat özgürlüğü anlayışını edebiyat sosyolojisi ve edebiyat, siyaset ilişkisi çerçevesinde incelemeyi olanaklı kıldığı gibi rejimin sanatçı algısını ve sanat anlayışını da ortaya koymaktadır. Bu anlamda sadece edebiyat sahasında değil güzel sanatların diğer alanlarında da sanatçlların ve eserlerinin rejimle etkileşimi ve eleştirel yaklaşımı çok yönlü ele alınabilirse sanat, politika etkileşimi geniş bir perspektifle değerlendirilebilir demek mümkündür. 
Sonuç olarak, Tek Parti döneminde, sansür ve yasaklamalarda sanatçlların siyasi görüşleri rejimi tehdit unsuru olarak algılanmış ve Sabahattin Ali, Necip Fazıl, Nihal Atsız gibi farklı görüşlerin sembol isimleri olan farklı kimlikleri de taşıyan sanatçılar iktidarı eleştirmiştir. Bunun neticesinde dışlanma ve cezalandırılma gibi müeyyidelere maruz kalmışlardır. İktidar, sanatçların görüşlerini içeren eserleri, milli ve manevi değerlere tehdit olarak görmüss ve sanatçlların eserlerinde siyasi görüşlerinin propagandasını yaptıkları gerekçesiyle yasaklandıklarını ileri sürmüş̧ür. Siyaset, sanat ve toplum ilişkisinde sanatçı, iktidar etkileşimi, karşılıklı konum alma biçimine göre eserlerin içeriklerini etkilediği gibi dönemin iktidarının toplumsal yapı üzerindeki etkisini de eserleri yoluyla sanatçının eleştirdiğini söylemek mümkündür.

\section{Kaynakça}

Akay, A. (1999). Sanatın Soyolojik Gözü. İstanbul: Bağlam.

Akün, F. (1991). "Hüseyin Nihal Atsız" Diyanet Vakfı İslam Ansiklopedisi. İstanbul. Diyanet Vakfı.

Ali, S. (1947). "Sırça Köşk”, Sırça Köşk, İstanbul: Remzi Kitabevi.

Alver, K. (2006). "Edebiyat Sosyolojisi ve Hayat”, Sosyoloji Dergisi, N: 15, Ege Üniversitesi Edebiyat Fakültesi.

Atsız, N. (1941). Dalkavuklar Gecesi, İstanbul: Aylı Kurt.

Atsız, N. (1992). Dalkavuklar Gecesi- Z Vitamini, İstanbul: Baysan Basım ve Yayın Sanayii.

Barthes, R. (2009) Yazı ve Yorum. İstanbul: Metis .

Bauman, Z. Mazzeo, R. (2019). Edebiyata Övgü İstanbul: Ayrıntı .

BOA:52-59: Başbakanlık Cumhuriyet Arşivi : Dosya: 52-59 Fon Kodu: 30.18.1.2 Yer No: 117.50.4.

Büyükarman, D. (2002). Yakup Kadri Karaosmanoğlu'nun İkdam Gazetesinde 1919-1922 Yılları Arasında Yazmış Olduğu Makalelerin Çevirimi- İncelenmesi. (BasılmamışYüksek Lisans Tezi). Kocaeli, 2002.

Ender Kamil Boyacı. (1982). "Sırça Köşk” Yazko Edebiyat. N:20.

Harrigton, A. (2019) "Sosyal Dünyanın Edebiyat Yoluyla Kavranması: Robert Musil'in Niteliksiz Adam Romanı Üzerine Sosyolojik Düşünceler”, (çev.Nurettin Çalışkan). Edebiyat Sosyolojisi İncelemeleri.(ed Köksal Alver). İstanbul: İz.

Kaplan, M. (1978). Edebiyatımızın İçinden. İstanbul:Dergah.

Karaosmanoğlu, Y. K. (1934). Ankara. Ankara: Akba.

Lowenthal, L. (2017). Edebiyat-Popüler-Kültür ve Toplum. İstanbul: Metis.

Merril, F. (2019) "Sosyolog Olarak Balzac: Bir Edebiyat Sosyolojisi İncelemesi”,(çev. Köksal Alver, Mustafa Fişne), Edebiyat Sosyolojisi İncelemeleri, (ed. Köksal Alver). İstanbul:İz.

Moodie, B. (2010). Using Fiction Sociologically, University of California, Berkeley.

Moran, Berna. (1990). Türk Romanına Eleştirel bir Bakış. II.Cilt. İstanbul: İletişim.

Okay, O. (2011). Poetika Dersleri. İstanbul: Dergah.

Orwell, G. (2017). Neden Yazıyorum. İstanbul: Sel.

Said, E. (2011). Entelektüel, İstanbul: Ayrıntı.

Şenderin, Z. (1996). Sabahattin Ali’nin Eserlerinde Toplumsal Gerçekçilik,(Basılmamış Yüksek Lisans Tezi), Kırıkkale. Kırıkkale Üniversitesi.

Topçu, N. (1998) “Çalgıcılar”, Taşralı. İstanbul: Dergah .

Topçu, N. (2001). Sosyoloji. İstanbul:Dergâh. 
294 / RumeliDE Journal of Language and Literature Studies 2019.16 (September)

Allegory and realistic regime criticism in the context of the relationship between literature and sociology / Y. Okay (p. 280-294)

Topçu, N. (2004). Kültür ve Medeniyet. İstanbul: Dergâh.

Topçu, N. (2006). Türkiye'nin Maarif Davası. İstanbul: Dergâh.

Wellek, R. - Warren, A. (1982). Yazın Kuramı. İstanbul: Altın Kitaplar. 